\title{
Revegetation of abandoned copper mines: the role of seed banks and soil amendments
}

\author{
A. Carvalho, C. Nabais, S. R. Roiloa, and S. Rodríguez-Echeverría \\ Centre for Functional Ecology, Department of Life Sciences, University of Coimbra, Coimbra, Portugal \\ Correspondence to: A. Carvalho (alp.carvalho1@gmail.com)
}

Received: 12 November 2012 - Revised: 22 August 2013 - Accepted: 5 September 2013 - Published: 16 September 2013

\begin{abstract}
Mining is one of the main causes of environmental pollution by heavy metals and (re)vegetation of mine spoils is the most effective method of preventing wind and water erosion and the consequent spread of contaminants to surrounding areas. However, plant establishment and growth are conditioned by some limiting factors of mine soils, such as low $\mathrm{pH}$, low fertility, high heavy metal concentration, and a small seed bank to initiate plant establishment. Improving soil physical and chemical properties is required in many cases for successful (re)vegetation programs.

In the copper mine of Touro, Galicia, Spain there is a large-scale project of soil amendment underway using technosols, a mixture of several organic residuals, to improve the conditions of mine soils. We evaluated the seed bank of several types of technosols, mine soil and soil from a control area outside the mine by studying seedling emergence in these soils. In a second experiment we evaluated the impact of increasing $\mathrm{pH}$ with liming and the admixing of nutrient-rich soil on the growth of two grasses (Lolium perenne and Dactylis glomerata) and two legumes (Medicago sativa and Trifolium subterrraneum) both sown individually and in mixtures.

Seedling emergence and species richness were highest in the technosols. Soil amendments promoted plant growth, with the addition of high-nutrient soil being the best amendment for the four plant species tested. Plant growth was impaired in the mine soil. Lolium perenne was the only plant species that germinated and grew in this soil. We found that soil amendments, either through the addition of technosols, $\mathrm{pH}$ buffering or nutrient enrichment, are essential for promoting the revegetation of mine areas.
\end{abstract}

1

Contaminated land is a problem worldwide, often resulting from the legacy of industrial activities, waste management practices, and mining activity (Gay and Korre, 2006) with a potential threat to human health (Vidali, 2001). Conventional techniques to recover the soil, as displacement, excavation or soil washing (Wu et al., 2012) can further contribute to contamination. To prevent these associated problems, other processes to clean up contaminated sites through techniques that decrease or eliminate contamination in situ are preferred (Prasad and Hagemeyer, 1999). One of these techniques is phytoremediation, an effective, relatively new technology that uses plants to remove toxic metals from the soil (Pilon-Smits, 2005; Pilon-Smits and Freeman, 2006) by using natural processes to degrade, assimilate or metabolize organic and inorganic pollutants (Susarla et al., 2002) present on contaminated soil, sludges, sediments, and ground water (U.S. EPA, 1999). Phytoremediation, which comprises various technologies using plants (Pilon-Smits and Freeman, 2006), can be applied to organic and inorganic pollutants and one of the major targets is heavy metals (Salt et al., 1998; Prasad and Hagemeyer, 1999), a major environmental problem (Anjum et al., 2012). Land contamination with metals can have irreversible effects on the environment (Haasea and Larondellea, 2012) since heavy metals cannot be degraded like organic contaminants (Ghosh and Singh, 2005; Jadia and Fulekar, 2009) or be broken into non-toxic forms (Jabeen et al., 2009).

Exposed mine areas have a strong impact on the environment (Álvarez et al., 2011) and revegetation is the most effective method to restore and integrate these areas into 
the surrounding landscape (Remon et al., 2005), decreasing the area exposed to erosion, limiting the spread of metals to nearby plant communities (Vega et al., 2006; Conesa et al., 2006; Mendez and Maier, 2008) and stabilizing the soil (Pilon-Smits and Freeman, 2006).

However, revegetation is not easy due to the fact that mine soils are usually acidic, with low fertility, low content of nutrients $(\mathrm{P}, \mathrm{Ca}, \mathrm{K})$, high concentrations of heavy metals, and high solubility of toxic metals (e.g., $\mathrm{Al}, \mathrm{Fe}, \mathrm{Mn}$ ) that impair plant growth (Tang et al., 2003; Kochian et al., 2004; Goransson et al., 2008). These factors slow down or prevent the revegetation process and consequent stabilization of mine tailings (Vega et al., 2004; O'Dell and Classesen, 2009).

Improving the physical and chemical properties of the soil is necessary for successful revegetation (Caravaca et al., 2003; O'Dell and Classesen, 2009). Soil amendments can change some physical-chemical properties of the soil, namely $\mathrm{pH}$, redox potential, cation exchange capacity and texture (Saxena et al., 1999). These soil properties have an effect on the availability and toxicity of heavy metals. It is known that a lower soil $\mathrm{pH}$ and redox potential enhances the mobility of most metals, rendering them more bioavailable (Mench et al., 2003). Also, high organic matter content enhances the retention of metals, reducing the availability for plant uptake of metals (Ross, 1994). In general, the application of organic matter and liming improve the revegetation potential in acidic soils contaminated with heavy metals (Córdova et al., 2011). The addition of organic matter has a beneficial effect on surface stability (Tisdall and Oades, 1982; Caravaca et al., 2003). When nutrients are added to the soil, not only does plant growth improve (Roldán et al., 2006) but the physical soil conditions are also ameliorated (Clemente et al., 2012). Soils with low or high $\mathrm{pH}$ are adverse for plant growth (Kobayashi et al., 2010) due to its effect on nutrient availability. Lime is a common amendment used to improve soil properties (Haynes and Naidu, 1998). Liming agents, such as calcium carbonate, can increase the $\mathrm{pH}$ of acidic soils (Levonmäki and Hartikainen, 2007), reducing the bioavailability of heavy metals (Little et al., 1991; Lee et al., 2004), and compensating for calcium losses (Persson et al., 1990).

Touro mine was an open pit in Galicia, Spain, for extraction of copper until 1988. The area exploited by this mine is associated with the Precambrian basic massif near Santiago de Compostela (Álvarez et al., 2010) and the geological substrate is amphibolite with amounts of $\mathrm{Fe}$ and $\mathrm{Cu}$ sulphides as pyrite, pyrrhotite, limonite and chalcopyrite (Calvo de Anta and Otero, 1994; Vega et al., 2006). The main characteristics included acidic soil, the high solubility of metals such as Al or Fe (Álvarez et al., 2010) and the high $\mathrm{Cu}$ content (Vega et al., 2005; Cerqueira et al., 2012). Restoration measures started at the beginning of 2003 with the addition of technosols, soils of technical origin constituted by human-made material (Asensio et al., 2008; IUSS, 2006), which improve the revegetation process by correcting the $\mathrm{pH}$ and/or adding nutrients, such as $\mathrm{P}$ and $\mathrm{N}$, mitigating the limiting conditions of mine soils (Asensio et al., 2013; Calvo et al., 1991).

We evaluated the potential seed bank, seed germination and plant growth on the mine soil and on different technosols. We tested the effects of organic matter addition and $\mathrm{pH}$ increase of mining soil on the growth of four native plant species, two grasses (Lolium perenne L. and Dactylis glomerata $\mathrm{L}$.) and two legumes (Medicago sativa $\mathrm{L}$. and Trifolium subterrraneum L.). The general objective of these experiments was to evaluate the efficacy of different strategies to improve the revegetation of abandoned mines.

\section{Materials and methods}

\subsection{Seed bank Assessment}

Eight soil types were collected within the open-pit copper mine, two of bare mine soil without any amendment (Mine-1 and Mine-2), and six of different types of technosols (Tec-0, Tec-1, Tec-2, Tec-2E, Tec-3, Tec-4). The average distance between the different sampling areas within the mine was about $100 \mathrm{~m}$. Soil was collected from an additional site at $2000 \mathrm{~m}$ from the edge of the open-pit mine, in an area without mining activity, as a reference control. In each soil type, four soil samples of about $1 \mathrm{~kg}$ were collected with a spade from the top $20 \mathrm{~cm}$ layer. All sampled technosols were made of urban waste and sludge from water treatment plants. The depth of the layer of technosol applied on top of the mine soil is $40-80 \mathrm{~cm}$. Areas covered with technosols were used for eucalypt plantations, as this is the main forestry in the area. The control soil outside the mine was also planted with eucalypts. Organic matter, $\mathrm{pH}, \mathrm{P}, \mathrm{K}$ and total $\mathrm{N}$ were analyzed as described previously (Rodriguez-Echeverría et al., 2009) from composite samples of each soil type. Soil $\mathrm{pH}$ was measured in soil suspensions in distilled water (LQARS, 1977). Soil organic matter was estimated after combustion of the samples at $550^{\circ} \mathrm{C}$ (Rossell et al., 2001). Total nitrogen was estimated following the Kjeldahl method (Bremner and Mulvaney, 1982). Available K and P were extracted by using ammonium lactate and acetic acid, and measured by using an atomic absorption spectrophotometer for K (Balbino, 1968) and a colorimetric method for P (Watanabe and Olsen, 1965). For a detailed description of each soil see Table 1.

Each soil sample was placed in $800 \mathrm{~cm}^{3}$ trays in a protected area at the Botanical Garden of Coimbra for 115 days, from 24 June until 17 October 2011. During the experimental period, trays were kept in the shade and watered regularly. Trays were monitored regularly from the beginning of the experiment, counting the number of emerged plants in each tray and estimating plant cover. Plant cover was estimated visually as the percentage of surface covered by vegetation. The identification of the species present in each tray began at day 73. We selected this day to check for differences in the number of plants germinated, using the Kruskal-Wallis 
Table 1. Coordinates and description of the dominant vegetation and soil chemical parameters for the different sampling points.

\begin{tabular}{|c|c|c|c|c|c|c|c|c|}
\hline $\begin{array}{l}\text { Sampling } \\
\text { point }\end{array}$ & Coordinates & Description & Vegetation & $\begin{array}{r}\text { O.M. } \\
(\%)\end{array}$ & $\mathrm{pH}$ & $\begin{array}{r}\mathrm{P} \\
\left(\mathrm{mg} \mathrm{kg}^{-1}\right)\end{array}$ & $\begin{array}{r}\mathrm{K} \\
\left(\mathrm{mg} \mathrm{kg}^{-1}\right)\end{array}$ & $\begin{array}{l}\text { Total N } \\
(\%)\end{array}$ \\
\hline Control & $42.89213^{\circ} \mathrm{N}, 8.35004^{\circ} \mathrm{W}$ & Outside the mine & Eucalypt plantation & 9.02 & 4.5 & 6 & 54 & 0.278 \\
\hline Mine-1 & $42.87536^{\circ} \mathrm{N}, 8.35345^{\circ} \mathrm{W}$ & Mine waste heap, slope & No vegetation & 4.31 & 4 & 33 & 59 & 0.16 \\
\hline Mine-2 & $42.87536^{\circ} \mathrm{N}, 8.35345^{\circ} \mathrm{W}$ & Mine waste heap, top & Ruderal annual plants & 4.31 & 4 & 33 & 59 & 0.16 \\
\hline Tec- 0 & $42.87678^{\circ} \mathrm{N}, 8.35209^{\circ} \mathrm{W}$ & Recently applied technosol & No vegetation & 8.34 & 8.1 & 1274 & 13 & 0.401 \\
\hline Tec-1 & $42.87704^{\circ} \mathrm{N}, 8.35434^{\circ} \mathrm{W}$ & Technosol & Eucalypt plantation & 8.76 & 7.9 & 1245 & 2975 & 0.471 \\
\hline Tec-2 & $42.87681^{\circ} \mathrm{N}, 8.35379^{\circ} \mathrm{W}$ & Technosol & Eucalypt plantation & 8.32 & 7.9 & 1306 & 994 & 0.229 \\
\hline Tec-2E & $42.87704^{\circ} \mathrm{N}, 8.35434^{\circ} \mathrm{W}$ & Technosol & Eucalypt plantation & 7.44 & 7.9 & 1199 & 957 & 0.203 \\
\hline Tec-3 & $42.88546^{\circ} \mathrm{N}, 8.35301^{\circ} \mathrm{W}$ & Technosol + mussel shells & Eucalypt plantation & 16.38 & 7.5 & 1302 & 433 & 0.554 \\
\hline Tec-4 & $42.88535^{\circ} \mathrm{N}, 8.35288^{\circ} \mathrm{W}$ & Technosol & Eucalypt plantation & 12.82 & 7.8 & 1213 & 311 & 0.322 \\
\hline
\end{tabular}

and Mann-Whitney tests (significance level of 0.05) using STATISTICA 7.

\subsection{Soil amendments}

The mine soil used in this experiment was collected in February 2012. About $20 \mathrm{~kg}$ of soil up to $20 \mathrm{~cm}$ from soil surface was collected from six places in the top of the mine waste, pooled and stored in plastic bags in a cool place until use.

Four treatments were used to test the effect of $\mathrm{pH}$ and nutrient amendments on plant growth in the mine soil. Garden soil was used as a control as it provided the best plant growth conditions. The other three treatments included the mine soil (Mine soil), mine soil amended with $\mathrm{CaCO}_{3}$ to increase soil $\mathrm{pH}\left(\right.$ Mine $\left.+\mathrm{CaCO}_{3}\right)$, and a mixture $1: 1(\mathrm{vol}: \mathrm{vol})$ of mine and garden soil (Mine + Garden) to improve texture and nutrient content.

Two grasses (Lolium perenne and Dactylis glomerata) and two legumes (Medicago sativa and Trifolium subterrraneum) commonly used in mine revegetation projects were selected for this study (Martínez-Ruiz et al., 2007). Seeds were purchased from a local commercial source. Two different experiments were prepared using the four soil treatments and plant species. The first experiment investigated the early growth of each individual plant species in each type of soil with two individuals per pot. The second experiment tested early plant growth in mixtures of the four species, using four individuals of each species per pot. All treatments had 10 replicates, in $150 \mathrm{~mL}$ pots for the first experiment and $1.5 \mathrm{~L}$ pots for plant mixtures. Seeds from the selected species were sown and pots were placed in a greenhouse at the Botanical Garden of Coimbra and watered regularly during 12 weeks.

To determine soil $\mathrm{pH}$, a fraction of the soil used in the four treatments was air dried and sieved through a $2 \mathrm{~mm}$ mesh. Subsequently, $5 \mathrm{~g}$ of soil was mixed with $50 \mathrm{~mL}$ of deionized water, stirred for $30 \mathrm{~min}$ and allowed to settle for $10 \mathrm{~min}$ and the $\mathrm{pH}$ was measured using an OAKTON pH meter (Page et al., 1982). Three replicates were used to determine soil $\mathrm{pH}$. The $\mathrm{pH}$ of the mine soil was 3.70 , the garden soil was 7.74 , the mixture of mine soil and garden soil was 7.07, and the addition of $\mathrm{CaCO}_{3}$ led to an increase of the mine soil $\mathrm{pH}$ up to 6.5. To reach this $\mathrm{pH}$ level, $2 \mathrm{~g}$ of $\mathrm{CaCO}_{3}$ were added to the $150 \mathrm{~mL}$ pots for the individual plant growth species experiment, and $25 \mathrm{~g}$ to the $1.5 \mathrm{~L}$ pots for the plant growth mixtures of the four species.

Total plant biomass and aboveground biomass were measured respectively for individual plants and for the mixture at the end of the experiment. Only aboveground biomass was harvested in the experiment of plant growth in mixtures due to the difficulty of separating the roots of each species.

One-way ANOVA and Tukey test were applied to check for differences in plant biomass for each plant species among the four types of soil (significance level of 0.05). All data were normally distributed, except for those of the biomass of $M$. sativa in the experiment of the mixture of species where they were transformed using $\log (n+1)$. These analyses were carried out using STATISTICA 7.

\section{Results}

\subsection{Seed bank assessment}

The mean number of plants that germinated in each soil type ranged from values close to zero in Mine-1, Mine-2 and Tec0 to around 100 individuals per $800 \mathrm{~cm}^{3}$ of soil in Tec-2, with significant differences $(p<0.05)$ among the different types of soils tested (Fig. 1).

The number of plants in the control soil reached around 70 per $800 \mathrm{~cm}^{3}$. In Mine- 1 there were no plants until day 66 and the maximum average number of individuals (6.25) was registered on day 94. In Mine-2 there were plants only in days 73 and 80 , with an average number of 0.25 individuals. There was a general increase in germination from day 56 onwards reaching a maximum around day 87 , and a general decrease in the number of plants found in each soil at the end of the experiment. Significant differences in the number of plants were found between the different treatments for day 73 (Fig. 2).

Plant cover was negligible in Mine-1, Mine-2 and Tec-0 due to a very low number of individuals. The three types of soil that showed a higher plant cover were, in decreasing order, Tec-3, Tec-4 and Tec-2 (Fig. 3). 


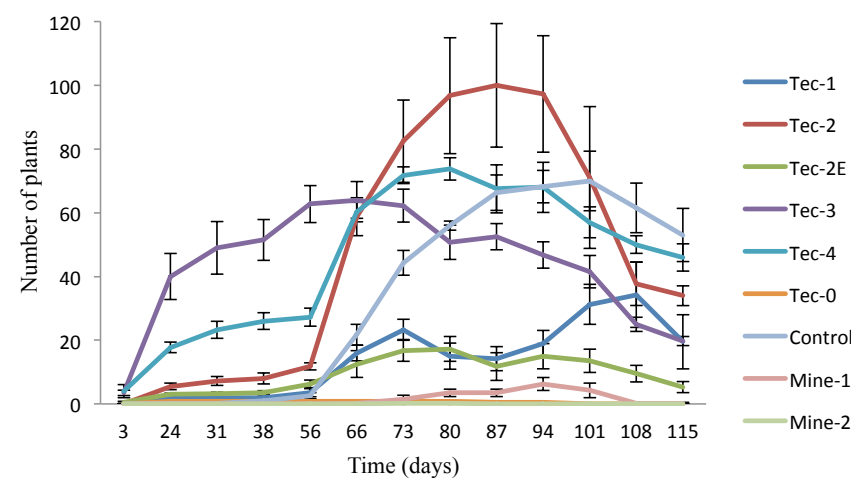

Figure 1. Number of individuals (mean \pm SE) in the experimental soils throughout the experiment.

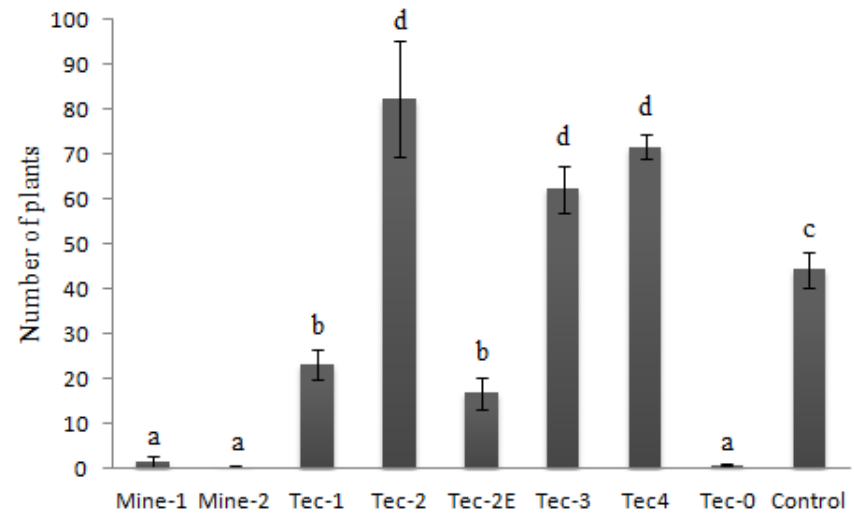

Figure 2. Number of individuals (mean \pm SE) at day 73. Different letters above bars mean significant differences between each soil type after non-parametric tests.

Fifteen plant species belonging to eight different families were identified during the experiment (Table S1), although most of the plants could not be identified during the seedling stage. All identified species were classified as ruderal. The identification of the few seedlings that emerged in Mine-1 and Mine- 2 was not possible due to the small size of the individuals. The most abundant species detected at day 73 were Sonchus oleraceus in Tec-0 and Tec-1, Parietaria judaica in Tec-2 and Control, Geranium purpureum in Tec-2E, Chelidonium majus in Tec-3 and Cardamine hirsuta in Tec4. The relative abundance of each identified species changed through time (Table S1).

\subsection{Soil amendments}

\subsubsection{Growth of individual plant species}

No plants survived at the end of the experiment in the Mine soil although $L$. perenne was able to germinate and grew for some weeks in this soil. Final plant biomass was highest in the Garden soil, followed by Mine + Garden and Mine + $\mathrm{CaCO}_{3}$. Significant differences were found among the three

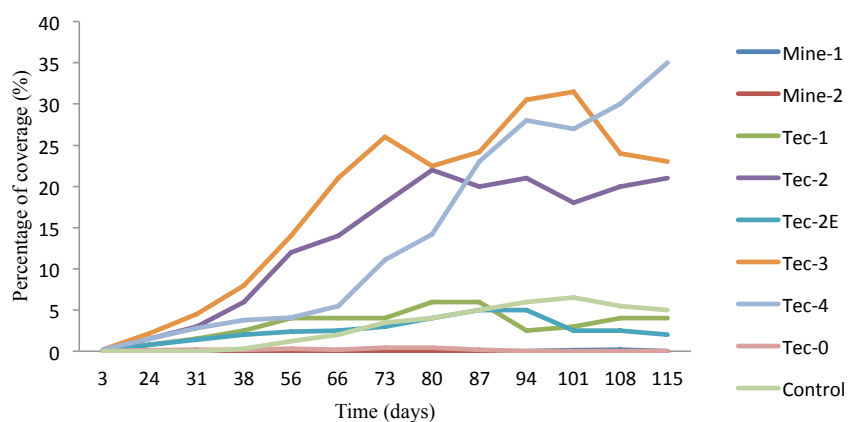

Figure 3. Percentage of plant cover for all types of soil throughout the experiment.

Table 2. $F$ and $P$ values of a One-way ANOVA testing the effect of treatment on the biomass of the four species grown individually in the Garden soil, Mine + Garden soil and Mine $+\mathrm{CaCO}_{3}$ soil.

\begin{tabular}{lll}
\hline Species & $F$ & $P$ \\
\hline Lolium perenne & 48.2763 & $<0.0001$ \\
Dactylis glomerata & 27.3733 & $<0.0001$ \\
Medicago sativa & 14.06937 & $<0.05$ \\
Trifolium subterraneum & 20.7649 & $<0.0001$ \\
\hline
\end{tabular}

treatments for L. perenne and T. subterraneum (Table 2, Fig. 4). Plant biomass was significantly lower in the Mine $+\mathrm{CaCO}_{3}$ treatment for D. glomerata and M. sativa, but no differences in the biomass of these species grown on the Garden soil and the Mine + Garden soil were detected (Table 2, Fig. 4). The lowest biomass for all species used was found in the treatment Mine $+\mathrm{CaCO}_{3}$, with $0.34 \mathrm{~g}$ for L. perenne, $0.12 \mathrm{~g}$ for D. glomerata, $0.07 \mathrm{~g}$ for M. sativa and $0.12 \mathrm{~g}$ for $T$. subterraneum.

\subsubsection{Plant growth in a mixture}

Lolium perenne was the only species that survived until the end of the experiment in the Mine soil. Significant differences in final plant biomass $(p<0.05)$ were found among the treatments in the four species analyzed (Table 3 ). Final plant biomass for all species except $L$. perenne was significantly lower in the Mine $+\mathrm{CaCO}_{3}$ treatment than in the Garden and Mine + Garden treatments (Table 3, Fig. 5). Differences in plant growth between these two last treatments were only found for $M$. sativa that had higher values of biomass in the Garden soil. For $L$. perenne, the lowest values of biomass were found in the Mine soil followed by Mine $+\mathrm{CaCO}_{3}$, and the highest values were found in the Garden soil and in the mixture Mine + Garden soil (Fig. 5).

Total plant biomass per pot was significantly higher $(p<0.001)$ in the Garden soil and in the Mine + Garden than in the other treatments, with values around $3 \mathrm{~g}$. Total plant biomass in the Mine $+\mathrm{CaCO}_{3}$ and Mine soils was below $0.5 \mathrm{~g}$ (Fig. 6). Significant differences in the relative 

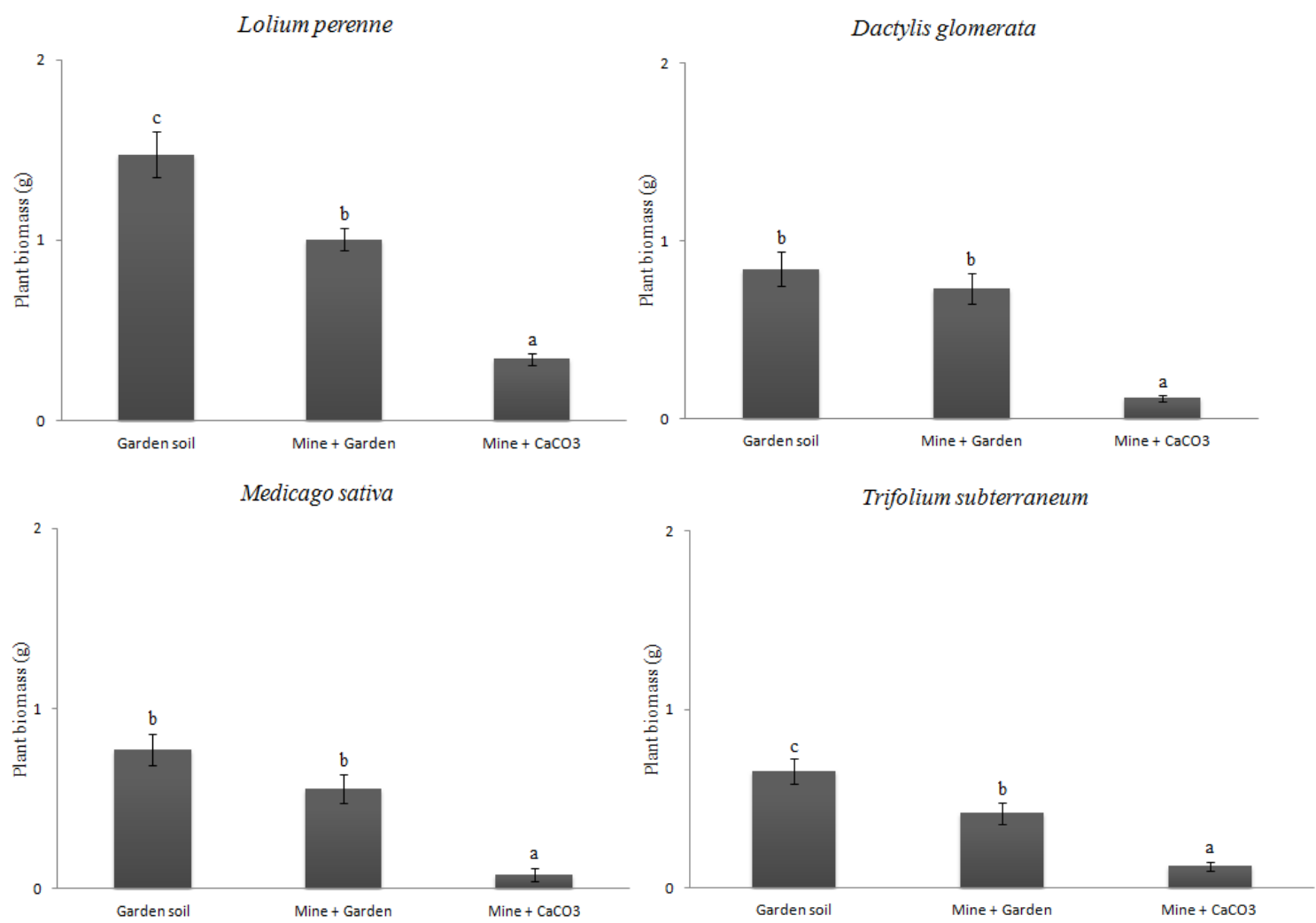

Figure 4. Total plant biomass (mean $\pm \mathrm{SE}$ ) in each treatment at the end of the individual pot experiment. Different letters above bars mean significant differences between each soil type after ANOVA and Tukey post hoc analysis.

Table 3. $F$ and $P$ values of a One-way ANOVA testing the effect of treatment on the biomass of the mixture of the four species grown in the Garden soil, Mine + Garden soil and Mine $+\mathrm{CaCO}_{3}$ soil.

\begin{tabular}{lll}
\hline Species & $F$ & $P$ \\
\hline Lolium perenne & 94.1991 & $<0.0001$ \\
Dactylis glomerata & 19.7236 & $<0.0001$ \\
Medicago sativa & 73.7213 & $<0.0001$ \\
Trifolium subterraneum & 16.71829 & $<0.0001$ \\
\hline
\end{tabular}

contribution of each species to total biomass were found for M. sativa and L. perenne. Medicago sativa grew better in the Garden soil than in the Mine + Garden, while the opposite was observed for L. perenne.

\section{Discussion}

\subsection{Seed bank assessment}

Mine soils (Mine-1 and Mine-2) revealed a very low potential for plant germination and growth. This is probably related to the occurrence of toxic levels of some heavy metals and a lower percentage of organic matter and total N, compared with the control soil. The $\mathrm{pH}(\sim 4)$ and $\mathrm{K}$ content were similar for the mine and control soils, with mine soils even showing a higher concentration of $\mathrm{P}$. However, a low $\mathrm{pH}$ increases the availability of heavy metals and this can have a negative effect on germination and seedling development (Marschner, 1991). This is aggravated by the fact that mine soils have a low seed bank. The Control soil proved to be significantly better for plant germination and growth than Mine soils. Although the content of $\mathrm{P}$ and $\mathrm{K}$ was lower and the $\mathrm{pH}$ was similar to the Mine soils, the Control soil showed a higher percentage of organic matter and N. Nitrogen is essential for plant growth and about $95 \%$ of the soil nitrogen is associated with organic matter (Meysner et al., 2006), which is strongly related to soil fertility (Johnston et al., 2009). Additionally, the Control soil had a well-established vegetation cover, which contributes to a more abundant soil seed bank than that present in the bare mine soil.

In general, compared with the Control soil, technosols showed a higher $\mathrm{pH}(\sim 8)$, a higher percentage of organic matter, especially Tec-3 and -4 , and higher levels of $\mathrm{P}$ and $\mathrm{K}$. All these parameters and a better physical structure due to the high organic matter content that favored seed germination and plant growth. Nonetheless, Tec-0 practically showed no germination. This technosol had been recently applied to the field, with a short time for the establishment of seeds from the surrounding areas. Tec-3, the soil with mussel shells, had 

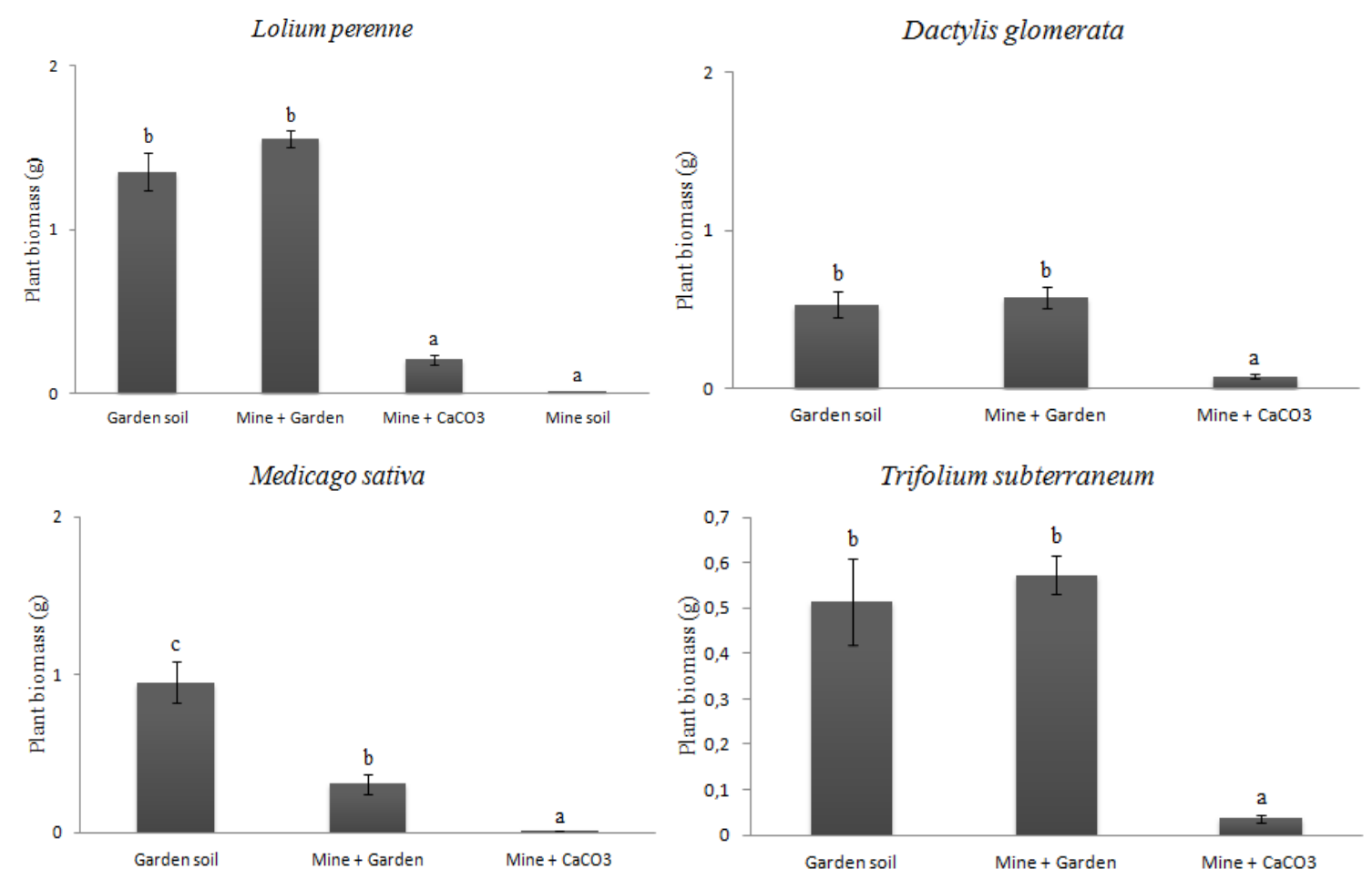

Figure 5. Aboveground biomass (mean $\pm \mathrm{SE}$ ) in each treatment at the end of the mixture of species experiment. Different letters above the bars mean significant differences between each soil type after ANOVA and Tukey post hoc analysis.

the highest percentage of organic matter and total $\mathrm{N}$ and it was the soil where germination occurred most rapidly. Mussel shell addition increases soil pH (Paz-Ferreiro et al., 2012) and stabilizes it over time (Álvarez et al., 2012). It also increases soil fertility when combined with other soil amendments and reduces the amount of available $\mathrm{Al}$ (Kwon et al., 2009). Plant cover showed the highest values in Tec-2, -3 and -4 . The high levels of $\mathrm{P}$ in these technosols, a limiting nutrient in many soils, probably contributed to the rapid growth of the seedlings. The seeds present in the technosols must come from the surrounding area through wind or animal dispersion. In fact, all soils showed a similar community of plants, confirming similar seed sources. However, there were some differences in the dominant species among the different tested soils. This indicates that there might be spatial differences in the distribution of seeds, or that some soils are better for the germination and growth of specific species, as it would be the case for Geranium purpureum in Tec-2E and Parietaria judaica in the Control and Tec-2 soils.

Our results showed that technosols, in general, facilitated plant germination and had a positive impact on the revegetation of bare mine soils. The application of a layer of these soils on top of the mine soil can thus stimulate the initial germination, growth and establishment of plants, accelerating the process of plant succession. Although we did not measure plant reproduction in these soils, plant species used in the process of revegetation must be able to reproduce for a successful revegetation project without further intervention upon seeding.

\subsection{Soil amendments}

Grasses are pioneers and usually are adapted to adverse conditions such as low soil nutrient content and shallow soils, with an important role in protecting soil from erosion (Hubbard, 1954). Legumes, through the process of nitrogen fixation, are important in the enrichment of soil with nitrogen, a limiting nutrient for plants (Wilson et al., 1982; Marschner, 1990; Snapp et al., 2005).

Lolium perenne was the only species able to grow in the mine soil, showing a good potential to be used for revegetation of mining areas. The other three species germinated but the seedlings did not survive more than two weeks.

In general, the growth of plants grown individually was higher in the Garden soil followed by Mine + Garden and Mine $+\mathrm{CaCO}_{3}$, showing a clear response to soil quality. However, differences were not found between Garden soil and Mine + Garden soil both for some individual species and for the total biomass of the mixture. This indicates that the mixture of species tested in this experiment could render good results after nutrient and organic matter amendment of mine soils. It is also noteworthy that plant growth was ameliorated just by an increase of $\mathrm{pH}$. The increase of soil $\mathrm{pH}$, 


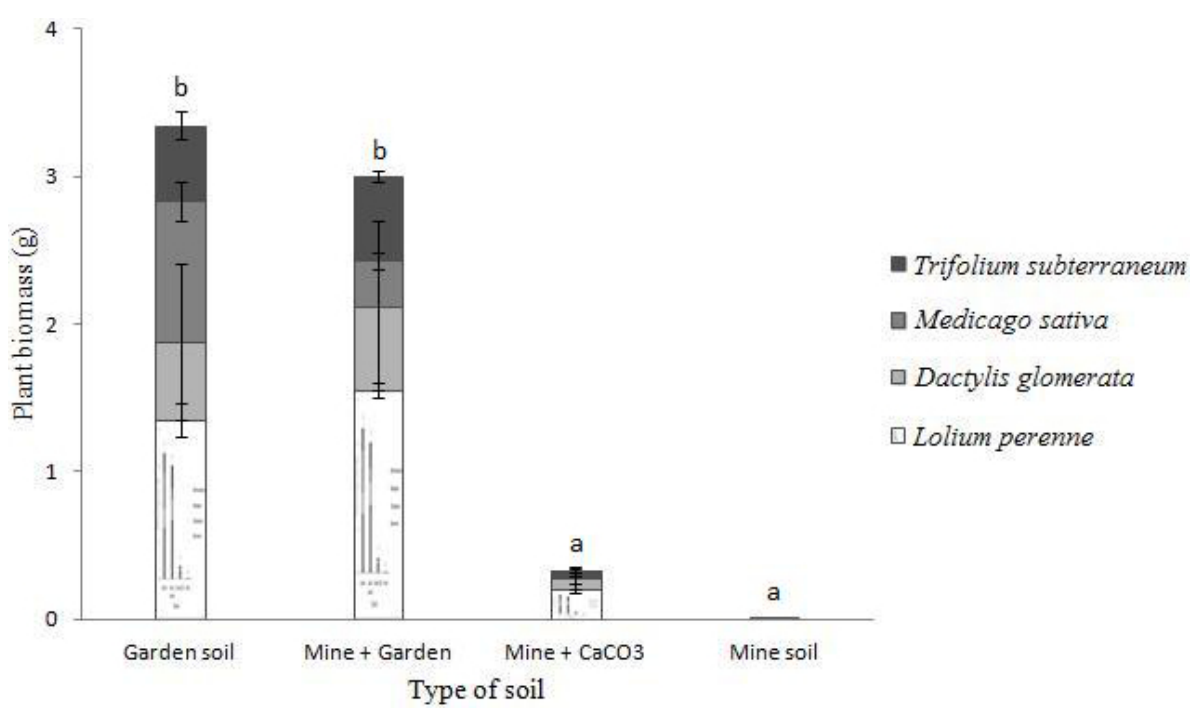

Figure 6. Total aboveground biomass (mean \pm SE) in each treatment at the end of the mixture of species experiment. Different letters above the bars mean significant differences between each soil type after ANOVA and Tukey post hoc analysis.

using liming agents reduces the mobility of heavy metals thus reducing toxicity for plants (Clemente et al., 2003).

When comparing the experiment with individual species and that where a mixture of species were grown, the two grasses had better growth in the mixture, while the legumes showed no differences between the two experiments. This indicates that competition among the species was not very strong and grasses benefited from the presence of legumes. It could also be related to the higher volume of the pots used for the mixture of species, with grasses having more soil to develop their roots. Nonetheless, the mixture of grasses and legumes in revegetation programs of mining soils is important because they represent two functional types of plants with different roles in the improvement of mine soils. Grasses, with their highly developed root system can stabilize the soils and reduce erosion, while legumes can add nitrogen to the soil, preparing the establishment of other plant species typical of later stages of succession (Tilman et al., 1996; Sanchez et al., 2001).

\section{Conclusions}

Mine soils have poor conditions for seed germination and plant growth, while in the technosols, a mixture of different types of organic residuals placed on the surface of contaminated soils, germination and development of plants was much higher, being effective in stimulating vegetation development. The high content of nutrients present in these technosols has a fundamental role in plant establishment and growth.

Seed banks are usually poor in mine areas and natural revegetation depends on the dispersion of seeds from surrounding areas. However, seed dispersion can be quite low, and in these cases, a mixture of seeds should be added to the area to improve vegetation growth.

In the greenhouse experiment, the grass $L$. perenne was the only species that could grow in the mine soil. The other species that were tested, D. glomerata, T. subterraneum and $M$. sativa, could not survive and establish in those soils. Increasing $\mathrm{pH}$ and/or adding a nutrient-rich soil can improve the growth of all species significantly, showing that ameliorating the stress associated with mine soils is essential for a successful revegetation of these soils.

\section{Supplementary material related to this article is available online at http://www.web-ecol.net/13/69/2013/ we-13-69-2013-supplement.pdf.}

Acknowledgements. We thank J. R. Verde and F. Macías from the Department of Soil Sciences of the University of Santiago de Compostela (Spain) for field assistance in Touro's copper mine. S. R. Roiloa was supported by a grant from the Portuguese Foundation for Science and Technology (FCT) (Reference: SFRH/BPD/79599/2011) co-funded by the European Social Fund of the European Union. The work was supported by a collaborative project between Spain and Portugal (HP2008-0093 and AE6/2009).

Edited by: L. Nagy

Reviewed by: N. Rajakurna and one anonymous referee 


\section{References}

Álvarez, E., Fernández-Sanjurjo, M., Otero, X. L. O., and Macías, F.: Aluminum speciation in the bulk and rhizospheric soil solution of the species colonizing an abandoned copper mine in Galicia (NW Spain), J. Soils Sediments, 11, 221-230, 2011.

Álvarez, E., Fernández-Sanjurjo, M. J., Otero, X. L., and Macías, F.: Aluminium geochemistry in the bulk and rhizospheric soil of the species colonising an abandoned copper mine in Galicia (NW Spain), J. Soils Sediments, 10, 1236-1245, 2010.

Álvarez, E., Fernández-Sanjurjo, M. J., Seco, N., and Núñez, A.: Use of Mussel Shells as a Soil Amendment: Effects on Bulk and Rhizosphere Soil and Pasture Production, Pedosphere, 22, 152164, 2012.

Anjum, N. A., Ahmad, I., Pereira, M. E., Duarte, A. C., Umar, S., and Khan, N. A. (Eds.): The Plant Family Brassicaceae. Contribution Towards Phytoremediation, Springer, Environ. Pollut., 21, 339 pp., 2012.

Asensio, V., Cancelo, B. C., Couce, M. L. A., Vega, F. A. V. and Covelo, E. F.: Efecto del Tratamiento con Tecnosoles en la Recuperación de Escombreras de Mina Ricas en Sulfuros Metálicos, Macla, 10, 107-110, 2008.

Asensio, V., Vega, F. A., Andrade, M. L., and Covelo, E. F.: Tree vegetation and waste amendments to improve the physical condition of copper mine soils, Chemosphere, 90, 603-610, 2013.

Balbino, L. R.: O método de Egnér-Riehm na determinação fósforo e do potássio "assimiláveis" em solos de Portugal, Rev. Agron., 51, 46-56, 1968.

Bremner, J. M. and Mulvaney, C. S.: Nitrogen-total, in: Methods of soil analysis. Part 2. Chemical and microbiological properties, 2nd Edn., edited by: Page, A. L., Miller, R. H., and Keeney, D. R., American Society of Agronomy Inc, Madison, Wisconsin, USA, 595-624, 1982.

Calvo de Anta, R. and Otero, A. P.: Soils affected by acid mine waters in Galicia (N.W. Spain), Water Air Soil Poll., 73, 247263, 1994.

Calvo, R., Otero, A. P., and Rodríguez, E. A.: Efectos de las minas de Arinteiro (La Coruña) sobre la calidad de aguas super y subsuperficiales, Ecología, 5, 87-100, 1991.

Caravaca, F., Figueroa, D., Alguacil, M. M., and Roldán, A.: Application of composted urban residue enhanced the performance of afforested shrub species in a degraded semiarid land, Bioresource Technol., 90, 65-70, 2003.

Cerqueira, B., Vega, F. A., Silva, L. F. O., and Andrade, L.: Effects of vegetation on chemical and mineralogical characteristics of soils developed on a decantation bank from a copper mine, Sci. Total Environ., 421-422, 220-229, 2012.

Clemente, R., Walker, D. J., Pardoa, T., Martínez-Fernández, D., and Bernala, M. P.: The use of a halophytic plant species and organic amendments for the remediation of a trace elementscontaminated soil under semi-arid conditions, J. Hazard Mater., 223-224, 63-71, 2012.

Clemente, R., Walker, D. J., Roig, A., and Bernal, M. P.: Heavy metal bioavailability in a soil affected by mineral sulphides contamination following the mine spillage at Aznalcóllar (Spain), Biodegradation, 14, 199-205, 2003.
Conesa, H. M., Faz, A., and Arnaldos, R.: Heavy metal accumulation and tolerance in plants from mine tailings of the semiarid Cartagena-La Unión mining district (SE Spain), Sci. Total Environ., 366, 1-11, 2006.

Córdova, S., Neaman, A., González, I., Ginocchio, R., and Fine, P.: The effect of lime and compost amendments on the potential for the revegetation of metal-polluted, acidic soils, Geoderma, 166, 135-144, 2011.

Gay, J. R. and Korre, A.: A spatially-evaluated methodology for assessing risk to a population from contaminated land, Environ. Pollut., 142, 227-234, 2006.

Ghosh, M. and Singh, S. P.: A review of heavy metals and utilization of its byproducts, Appl. Ecol. Env. Res., 3, 1-18, 2005.

Goransson, P., Olsson, P. A., Postma, J., and Falkengren-Grerup, U.: Colonisation by arbuscular mycorrhizal and fine endophytic fungi in four woodland grasses - variation in relation to $\mathrm{pH}$ and aluminium, Soil Biol. Biochem., 40, 2260-2265, 2008.

Haasea, D. and Larondellea, N.: Valuing post-mining landscapes using an ecosystem services approach - An example from Germany, Ecol. Indic., 18, 567-574, 2012.

Haynes, R. J. and Naidu, R.: Influence of lime, fertilizer and manure applications on soil organic matter content and soil physical conditions: a review, Nutr. Cycl. Agroecosys., 51, 123-137, 1998.

Hubbard, C. E.: Grasses: A guide to their structure, identification, uses, and distribution in the British Isles, 1st Edn., Penguin Books, 402 pp., 1954.

IUSS Working Group WRB: World reference base for soil resources 2006, World Soil Resources Reports No. 103, FAO, Rome, 2006.

Jabeen, R., Ahmad, A., and Iqbal, M.: Phytoremediation of Heavy Metals: Physiological and Molecular Mechanisms, Bot. Rev., 75, 339-364, 2009.

Jadia, C. D. and Fulekar, M. H.: Phytoremediation of heavy metals: recent techniques, Afr. J. Biotechnol., 8, 921-928, 2009.

Johnston, A. E., Poulton, P. R., and Coleman, K.: Soil organic matter: its importance in sustainable agriculture and Carbon dioxide fluxes, Adv. Agron., 101, 1-57, 2009.

Kobayashi, O., Higuchi, K., Miwa, E., and Tadano, T.: Growth injury induced by high $\mathrm{pH}$ in rice and tomato, Soil. Sci. Plant Nutr., 56, 407-411, 2010.

Kochian, L. V., Hoekenga, O. A., and Piñeros, M. A.: How do crop plants tolerate acid soils? Mechanisms of aluminium tolerance and phosphorous efficiency, Annu. Rev. Plant Biol., 55, 459-493, 2004.

Kwon, Y. T., Lee, C. W., and Yun, J. H.: Development of vermicast from sludge and powdered oyster shell, J. Clean Prod., 17, 708711, 2009.

Lee, T. M., Lai, H. Y., and Chen, Z. S.: Effect of chemical amendments on the concentration of cadmium and lead in long-term contaminated soils, Chemosphere, 57, 1459-1471, 2004.

Levonmäki, M. and Hartikainen, H.: Efficiency of liming in controlling the mobility of lead in shooting range soils as assessed by different experimental approaches, Sci. Total Environ., 388, $1-7,2007$.

Little, D. A., Reneau Jr., R. B., and Martens, D. C.: Limestabilized and chemically-fixed sewage sludges as lime amendments, Bioresource Technol., 37, 93-102, 1991.

LQARS: Ministério da Agricultura, Lisboa, Portugal, 1977. 
Marschner, H.: Mineral Nutrition of Higher Plants, Academic Press, London, 4th Edn., 674 pp., 1990.

Marschner, H.: Mechanisms of adaptation of plants to acid soils, Plant Soil, 134, 1-20, 1991.

Martínez-Ruiz, C., Fernández-Santos, B., Putwain, P. D., and Fernández-Gómez, M. J.: Natural and man-indiced revegetation on mining wastes: Changes in the floristic composition during early succession, Ecol. Eng., 30, 286-294, 2007.

Mench, M., Bussiere, S., Boisson, J., Castaing, E., Vangronsveld, J., Ruttens, A., De Koe, T., Bleeker, P., Assunção, A., and Manceau, A., Progress in remediation and revegetation of the barren Jales gold mine spoil after in situ treatments, Plant Soil, 249, 187-202, 2003.

Mendez, M. O. and Maier, R. M.: Phytostabilization of Mine Tailings in Arid and Semiarid Environments - An Emerging Remediation Technology, Environ. Health Persp., 116, 278-283, 2008.

Meysner, T., Szajdak, L., and Kus, J.: Impact of the farming systems on the content of biologically active substrates and the forms of nitrogen in the soils, Agronomy Research, 4, 531-542, 2006.

O'Dell, R. E. and Classesen, V. P.: Serpentine Revegetation: A Review, Northeast Nat., 16, 253-271, 2009.

Page, A. L., Miller, R. H., and Keeney, D. R.: Methods of Soil Analysis. Part 2. Chemical and Microbiological Properties, 2nd Edn., Madison, Wisconsin, USA, 1159 pp., 1982.

Paz-Ferreiro, J., Baez-Bernal, D., Insúa, J. C., and Pomar, M. I. C.: Effects of mussel shell addition on the chemical and biological properties of a Cambisol, Chemosphere, 86, 1117-1121, 2012.

Persson, T., Wirén, A., And Andersson, S.: Effects of liming on Carbon and Nitrogen mineralization in coniferous forests, Water Air Soil Poll., 54, 351-364, 1990.

Pilon-Smits, E. A. H.: Phytoremediation, Annu. Rev. Plant Biol., 56, 15-39, 2005.

Pilon-Smits, E. A. H. and Freeman, J. L.: Environmental cleanup using plants: biotechnological advances and ecological considerations, Front Ecol. Environ., 4, 203-210, 2006.

Prasad, M. N. V. and Hagemeyer, J. (Eds.): Heavy Metals Stress in Plants - From Molecules to Ecosystems, Springer, Berlin, 401 pp., 1999.

Remon, E., Bouchardon, J. L., Cornier, B., Guy, B., Leclerc, J. C., and Faure, O.: Soil characteristics, heavy metal availability and vegetation recovery at a former metallurgical landfill: implications in risk assessment and site restoration, Environ Pollut., 137, 316-323, 2005.

Rodríguez-Echeverría, S., Crisóstomo, J. A., Nabais, C., and Freitas, H.: Belowground mutualists and the invasive ability of Acacia longifolia in coastal dunes of Portugal, Biol. Invasions, 11, 651-661, 2009.

Roldán, A., Carrasco, L., and Caravaca, F.: Stability of desiccated rhizosphere soil aggregates of mycorrhizal Juniperus oxycedrus grown in a desertified soil amended with a composted organic residue, Soil Biol. Biochem., 38, 2722-2730, 2006.

Ross, S. M.: Retention, transformation and mobility of toxic metals in soils, in: Toxic Metals in Soil-Plant Systems, edited by: Ross, S. M., John Wiley and Sons, Chichester, 63-152, 1994.
Rossell, R. A., Gasparoni, J. C., and Galantini, J. A.: Soil organic matter evaluation, in: Assessments methods for soil carbon, edited by: Lal, R., Kimble, J. M., Follett, R. F., and Stewart, B. A., Lewis Publishers, USA, 676 pp., 2001.

Salt, D. E., Smith, R. D., and Raskin, I.: Phytoremediation, Annu. Rev. Plant Phys., 49, 643-68, 1998.

Sanchez, J. E., Willson, T. C., Kizilkaya, K., Parker, E., and Harwood, R. R.: Enhancing the Mineralizable Nitrogen Pool Through Substrate Diversity in Long Term Cropping Systems, Soil Sci. Soc. Am. J., 65, 1442-1447, 2001.

Saxena, P. K., KrishnaRaj, S., Dan, T., Perras, M. R., and Vettakkorumakankav, N. N.: Phytoremediation of Heavy Metal Contaminated and Polluted Soils, in: Heavy Metal Stress. Plants: From Molecules to Ecosystems, edited by: Prasad, M. N. V. and Hagemeyer, J., Springer, Berlin, 305-329, 1999.

Snapp, S. S., Swinton, S. M., Labarta, R., Mutch, D., Black, J. R., Leep, R., Nyiraneza, J., and O’Neil, K.: Evaluating Cover Crops for Benefits, Costs and Performance within Cropping System Niches, Agron. J., 97, 322-332, 2005.

Susarla, S., Medina, V. F., and McCutcheon, S. C.: Phytoremediation: An ecological solution to organic chemical contamination, Ecol. Eng., 18, 647-658, 2002.

Tang, C., Regel, Z., Diatloff, E., and Gazeyc, C.: Responses of wheat and barley to liming on a sandy soil with subsoil acidity, Field Crop. Res., 80, 235-244, 2003.

Tilman, D., Wedin, D., and Knops, J.: Productivity and sustainability influenced by biodiversity in grassland ecosystems, Nature, 379, 718-720, 1996.

Tisdall, J. M. and Oades, J. M.: Organic matter and water-stable aggregates in soils, J. Soil Sci., 33, 141-163, 1982.

U.S. EPA: Phytoremediation Resource Guide, EPA/542/B-99/003, available at: http://www.epa.gov/tio, 1999.

Vega, F. A., Covelo, E. F., and Andrade, M. L.: Limiting factors for reflorestation of mine spoils from Galicia (Spain), Land Degrad. Dev., 16, 27-36, 2005.

Vega, F. A., Covelo, E. F., and Andrade, M. L.: Competitive sorption and desorption of heavy metals in mine soils: Influence of mine soil characteristics, J. Colloid. Interf. Sci., 298, 582-592, 2006.

Vega, F. A., Covelo, E. F., Andrade, M. L., and Marcet, P.: Relationships between heavy metals content and soil properties in minesoils, Anal. Chim. Acta, 524, 141-150, 2004.

Vidali, M.: Bioremediation. An overview, Pure Appl. Chem., 73, 1163-1172, 2001.

Watanabe, F. S. and Olsen S. R.: Test of an ascorbic acid method for determining phosphorus in water and $\mathrm{NaHCO}_{3}$ extracts from soil, Soil. Sci. Soc. Am. Proc., 29, 677-678, 1965.

Wilson, G. F., Lal, R., and Okigbo, B. N.: Effects of cover crops on soil structure and yield of subsequent arable crops grown under strip tillage on an eroded Alfisol, Soil Till. Res., 2, 233-250, 1982.

Wu, L., Li, Z., Han, C., Liu, L., Teng, Y., Sun, X., Pan, C., Huang, Y., Luo, Y., and Christie, P.: Phytoremediation of soil contaminated with Cadmium, Copper and Polychlorinated biphenyls, Int. J. Phytoremediat., 14, 570-584, 2012. 